\title{
TECHNICAL LANGUAGE AS A CREATOR OF TECHNICAL CAULTURE AND POPULAR CULTURE
}

\section{Waldemar LIB}

\begin{abstract}
The article tackles a very important issue nowadays, which is the notion of a technical language and its influence on technical culture and popular culture.
\end{abstract}

Key words: culture, technical culture, communication, technical language.

\section{JEZZYK TECHNICZNY KREATOREM KULTURY TECHNICZNEJ I KULTURY POWSZECHNEJ}

Streszczenie: $W$ artykule poruszana jest niezwykle ważna $w$ dzisiejszych czasach problematyka języka technicznego, jego wpływu na kulturę techniczna i ich zwiąku z kultura powszechna.

Słowa kluczowe: kultura, kultura techniczna, komunikacja, język techniczny.

\section{Culture, culture and communication}

Culture belongs to the basic notions of contemporary humanities [Kłoskowska 2005: 9]. Nowadays, we may encounter many approaches to culture, what results in the fact that the notion "culture" has become a slogan to begin certain associations, mostly connected with propaganda, entertainment and the reception time of art works as well as popular art. Culture as a phenomenon is also tackled in the field of psychology, sociology, history and others. Such different perception of culture is the proof for the fact that it is mainly understood by means of supposition or spontaneous judgment in this field.

Culture is the whole of principles, regulations and ways of people's actions, including human work as well their creativity. Culture is a collective property of human societies, established on the basis of peculiar biological and social features of man and the conditions of his/her living. It develops and transfers within the historical process, it also constitutes the historical stage of society development process, perceived by the level of control over the nature powers achieved state of knowledge and artistic creativity as well as forms of contemporary living and social co-existence [see Furmanek 1998: 123 $-127]$.

The natural environment of man is not only the world of nature but also, to greater extent, so called the world of culture, established permanently by human beings themselves [Krapiec 1996: 47]. Moreover, this world is the outcome of the development of technical means which were used, at the beginning, in a limited scope (available only for limited groups) known further to the whole of the society. Including them into the ones that are widely and commonly used, culture modifies behaviour and conduct of man. As a result, the development of a technical language (the content of a meaning and pragmatics) is an indispensible component of a technical culture.

Talking about culture, we shall not forget about communication. M. Czerwiński [1985: 20] in the book Wspólnota komunikacyjna [Communication Community] states that if culture is tackled from an individual perspective, such approach shall depict the fact that in this capacity culture constitutes a system of connected ideas and objects as well as the system of the processes shaping the means of expression (as well and may be mostly verbal means of communication i.e. words). Mutual communication among people is possible only within the common culture which encompasses the system of gestures, signs, behaviour and customs, expressions, images, informal language and systems of language codes [see Furmanek 1998: 127] presenting i.a. scientific language which incorporates technical notions.

S. Kaczor claims that the ability of communication, public appearance and presenting one's thought demands on a paper in the name of a group while preserving the respect for another person who is the addressee, especially when it has a critical character, is the determinant of social and moral qualifications of people who do not care for cultural factors. Kwiatkowski 2004: 40-44].

An individual has been permanently creating their culture since their appearance on the Earth 
and the branches of human culture - as rightly claimed by M.Krąpiec [1996] shall be visible in four main fields:

1. In the pre-scientific and scientific comprehension, in the various concepts of sciences and their social institutions.

2. In the moral conduct both individual and social, along with customs and traditions.

3. In the works of technology and art.

4. In the religion practiced individually and socially [Krąpiec 1996: 5].

The most interesting point of view is the cultural aspect connected with technology and technical works that is why the further shall be devoted to this aspect of culture.

\section{Technical culture}

The influence of technology on culture is proven by the fact that the process of creating culture is inseparably connected with the development of technology. Apparently it is noticeable that the names of particular human culture epochs have derived from technology since ages, particularly, from the role of tools within the civilisation development which have been used by people, that is why we have the culture of the Neolithic Age, the Palaeolithic Age, the Bronze Age, the Iron Age, Culture of Steam (or Steam Century), Electricity, Atom, IT and Information.

The notions of information culture and their connotations with the culture of man was tackled in detail by T.Piątek (2002) and his analysis presented i.a. the study titled Information Culture as the Component of General Culture.

It is really difficult to define explicitly the notions of technical culture, due to the fact that the notion of culture has not been explicitly defined yet, as the notion of technology is not explicit and differently approached by many experts in this field of knowledge. Due to the fact that the term culture has some meanings there is a need to interpret this notion in such a way that would include all aspect of people's actions which are of historical character. Such phenomenon is technology. As a consequence, it is essential to offer a definition of technical culture which is the set of two designates culture and technology. Some authors define technical culture broadly, globally as a component of culture in general, others define it as a theoretical construct for determining the personal features of a human being.

Technical culture from a global perspective refers to the content and the whole of the results of technical activity. It is also a material and nonmaterial (e.g. technical knowledge, technical notions) of social property aimed at developing and modifying the nature. Such technical culture encompasses the level of social awareness depicting the assessment, opinions and outlooks on the technical system and its particular elements as well as their results, knowledge, skills and habits significant for a given society in accordance with the functioning system of values.

The definition of technical culture from a global perspective, is an attempt to determine it by H. Pochanke (1980) who the notion of technical culture defines as follows: ...technical culture constitutes the whole of human property in the field of science and technical devices and at the same time, the whole of skills (based on proper knowledge) embodied in the manner of using this property, developing it and transferring it - along with appropriate skills to the young generation [Pochanke 1980: 62].

In this definition, the author encompasses both the object side as well as the subject side of technical culture.

J. Bańka (1983) writes, technical culture shall be understood as a set of thinking projects which are correlated with a certain technical object or a set of internationalised skills as well as ways of thinking and actions determining the acquirement of material goods. In other words, technical culture shall encompass mental patterns of actions and the techniques possible to implement, and at least possible due to the development of human knowledge and practice [Bańka 1983: 93].

Such understanding of the notion of technical culture refers, excluding its content, to the whole of the content in its technical activity.

As a personal feature, technical culture (as defined previously) is the theoretical construct for defining the personal features of a human being. The author considering this fact that is i.a. T. Nowacki emphasising the skills of optimal use of technology by man and writes... technical culture is expressed in adjusting human activities to the technical devices within a proper, i.e. optimal use of the possibilities given by technology, skills of using each device in accordance with its construction and function. Technical culture is expressed in proper operation of technical devices as well as in their designing and manufacturing [Nowacki 1969: $15]$. 
Such approach to technical culture may be, according to T.Nowacki, defined on three levels:

1. Level encompassing the users of technical goods and materials included in the use of natural environment of a human being.

2. Level encompassing producers, that is why the scope of technological production skills, manufacturing of usable objects construction goods.

3. Level encompassing the technology manufactures and organisers of social and economic life, including designers, constructors, architects and inventors etc. [Krowicki 1998: 90].

Generally, it may be claimed that technical culture from a personal perspective is rational, flexible and socially useful relation of an individual to technology and the use of technology for improving the level of spiritual life, economic level, social life and everyday life in compliance with the state of technological progress. In such definition of technical culture there are three connected elements of the relation human-technology.

1. Operative, basic technical knowledge (combined with a technical language and its material which are technical notions), allowing for understanding technology, assessment itself and its products and developing a creative attitude towards it.

2. Technical intellectual and manual skills which allows for reasonable operation of technical devices and tools as well as manufacturing new material goods of technical character.

3. Attitudes towards technology, depicted in the interests and engagement in the issues of technology and responsibility of each human being for the results of technical activity [Wołk 1990: 11].

The basic element of technical culture is perceived as the skills connected with technical activity encompassing the range of motor activities related to the use of technical devices during processing materials into new products as well as the service activity and intellectual activities indispensible while designing technical products and planning production processes, searching for the reasons for the ineffectiveness of technical products and connected with the process of passing technical information verbally, by means of words i.e. by proper command of technical notions as well as by other means of expression and coding information.

The important element that influences the results of the technical activity is also a social and moral attitude revealed while dealing with technology. It is expressed by the human's relation to phenomena, processes and technical products and also in the relation to technical activity. Reasonable and responsible dealing with technology and its products requires the knowledge of its regulations, principles and regularities. It may be provided only by proper knowledge on construction and operation of technical products of energetic, technological and organisation bases of manufacturing processes about the principles of using technical devices and of the significance of technology within the national economy. Such knowledge constitutes a major component of technical, may be acquired by a person having rich vocabulary of understood technical notions because thanks to a language and words such knowledge is saved, stored and transferred.

\section{Technical language and technical culture}

A very important component of technical culture is a technical language and its products which are technical notions.

As it was mentioned, a language is a tool of thinking, thoughts are the reflection of reality in the people's mind. As it was mentioned, a language is a tool of thinking, thoughts are the reflection of reality in the people's mind. These changes are the causative measures and drive forces for the development of a language. A language is also a means of social interaction and that is why it is a necessary condition of satisfactory and efficient communication among group members in order to perform a common activity and especially to achieve own and socially beneficial aims. Practical use of tools and symbolic forms of activity connected with speech constitute a complex psychological unit in which symbolic activity is aimed at organising practical operations by means of creating second degree stimuli and planning its own actions. The causative measures shall encompass among others: social and political, cultural and educational determinants and technology [Bajerowa 2003: 5].

Their meaning and influence of technical vocabulary on the development of culture is the fact that among many changes which are experienced at the turn of $20^{\text {th }}$ and 21th to which belong demographic, social, ideological, geopolitical, cultural and civilization changes that are the most significant for our future constitute the ones connected with the changes in science and technology [Furmanek, Walat 2002: 15]. The 
changes are also reflected in the language which is used.

I. Bajerowa [1980: 3] writes that it is necessary to pay attention to the influence of the technique which by means of permanent (faster) development is a distinctive feature of our times. It also contemporary hope and threat for human kind, so the force on which depends the whole of our social living including our language.

Dependence of a language upon technology was carried out when man constructed and named the very first tools - the moment of introducing technical vocabulary [Bajerowa 1980: 5]. A vast number of technical terms has accumulated since the moment of creating the very first technical notions till the contemporary times. Technical vocabulary seized to be only a matter of language culture, it is mostly a tool of work, on which accuracy and precision from material tool is demanded.

In the book Outline of the Polish language history in the years 1939-2000 in the chapter Technology as the causative determinant I. Bajerowa [2003] specifying concrete technical phenomena and their influence on the development of the Polish language. There can be included the development of mass media such as: radio, television, tape recorder, video player, photocopiers, computers, Internet and also the development of communication in the scope of road transportation (both public and private), rail and air transportation of general electrification of the country, completely finished in the 1970s and determining the use of modern media. Moreover, the author recalls the influence of dozens of inventions which did not have the direct influence on a general situation of the Polish language, though they enriched its vocabulary with many neologisms filled with the overall language in the process of so called terminologisation. She writes that the technology is the basic feature determining the language communication, upon which quality and range of information channels depend [Bajerowa 2003: 46-50].

The number of technical terms decide on the meaning of technical vocabulary in the communication processes, i.e. developing the technical culture of man. It is also connected with rapid development of technical knowledge in the scope of particular fields of technology as well as deeper mutual penetration and engaging many different, mostly distant fields of this knowledge. This penetrates all walks of everyday life, both at home and work - especially the vocabulary needed for purchasing, expressing their own thoughts, needs, wants, discussing the manner of repair, reading a book, newspaper, understanding messages and opinions of the represented in the television and radio programmes etc.

It is the cause that not only engineers and technicians, educating or specialising in certain fields of technical knowledge, deal with technical vocabulary but also the whole of the society, almost all the time they deal with technical notions as well as are connected with the problems of understanding and use of these notions.

The aforementioned fact reveals the inseparable relation between the technical language and technical culture is the cause for existing the needs of popularisation among the people not directly connected with the technical activity of all fields of technical knowledge especially the vocabulary belonging and developing in a very fast pace.

Another significant meaning has the precise, detailed, not ambiguous and mistaken, naming in the industry of devices, machines, process tools and ways of manufacturing the technical products. As well as for theses aims, the technical names must be comprehensible for the recipients without adding explanation.

The aforementioned results in an increase in vocabulary belonging to particular fields of technology as well as in an increase in general vocabulary, used every day.

Another very significant factor influencing the specific meaning of technical vocabulary is a major increase in technical literature, both in form of concise works and numerous press titles dealing with many fields of technology (e.g. construction, photography, motorisation, IT etc.) We everyday experience many messages encompassing some technical notions, norms, documents and instructions (e.g. manuals washing machine manuals - including a vast range of technical vocabulary).

What is more, on the radio and television there are many programmes aimed at many groups of recipients and devoted to technology, its various aspects and phases of the activity compliant with seven phases of technical activity of man - starting with recognition by designing, constructing, planning of actions, production, operation, maintenance and liquidation [Walat 2004: 13].

Due to so much amount of various studies and programmes of a technical character or 
encompassing technical notions and terms, it is important and even indispensible to have some necessary technical vocabulary. The vocabulary that will be known and used properly.

\section{Conclusion}

Development of modern means of technology, which are currently experienced and their anticipated influence on man's life, in a further perspective, with a special emphasis on education defined by R.Pachociński [2002] in the book titled Technology vs. education and the fact that a language is one of the most basic components creating and developing culture of a society, confirms that a technical language is a crucially important component of technical culture and its development by its considerable influence on the development of the Polish language, has its enormous contribution to the development of culture in general.

\section{Bibliography:}

(1) Bajerowa I.: Wptyw techniki na ewolucje języka polskiego [Influence of technology on the evolution of the Polish language]. issued by Zakład Narodowy Imienia Ossolińskich, Kraków 1980.

(2) Bajerowa I.: Zarys historii języka polskiego[The outline of the history of the Polish language] 1939-2000. issued by PWN, Warszawa 2003.

(3) Bańka J.: Ja teraz. U źródet filozofii człowieka wspótczesnego. [Now me. At the beginning of contemporary man' philosophy] issued by Śląsk, Katowice, 1983.

(4) Czerwiński M.: Wspólnota komunikacyjna.[Communication community] issued by COMUK, Warszawa 1985.

(5) Furmanek W., Walat W.: Przewodnik metodyczny dla nauczycieli techniki-informatyki.

Klasa 4 szkoty podstawowej. [Methodology guide for technology-IT teachers. 4th grade of primary school] issued by Fosze, Rzeszów 2002.

(6) Furmanek W.: Zrozumieć technikę. [Understand technology] issued by WO FOSZE, Rzeszów 1998.

(7) Kaczor S.: Kwalifikacje spoleczno-moralne $i$ ich rosnace znaczenie $w$ życiu. [Social and moral qualifications and its incresing significance in life] [w:] Kwalifikacje zawodowe na wspótczesnym rynku pracy. [Professional qualifications in the labour market] under supervision of S. M. Kwiatkowski issued by IBE, Warszawa 2004.

(8) Kłoskowska A.: Kultura masowa. [Mass culture] issued by PWN, Warszawa 2005.

(9) Krapiec M.: Czlowiek w kulturze. [Man in culture] issued by Gutenberg - Print, Warszawa 1996.

(10) Krowicki L.: Kultura techniczna problematyka metodologiczna. [Technical culture - mothodological issues] M.A thesis under supervision of prof. W. Furmanek Rzeszów 1998.

(11) Nowacki T.: O kulturze technicznej. [About technical culture] Zielona Góra 1969.

(12) Pachociński R.: Technologia a oświata. [Technology vs. education] issued by IBE, Warszawa 2002.

(13) Pochanke H.: Upowszechnienie kultury technicznej wśród dzieci $i$ mtodzieży. [Popularisation of technical culture among children and teenagers] issued by Zielona Góra 1980.

(14) Piatek T.: Kultura informacyjna komponentem kultury ogólnej, [Information culture as a component of general culture] [w:], Zbornik prispevkow $z$ medzinárodnej vedecko odbornej konferencie "Technické uzdelanie ako súćast vśeobecného vzdelania", ed. Dubovská R. issued by Univerzita Mateja Bela, Banska Bystrica, 2002. (15) Walat W.: Modelowanie podręczników techniki-informatyki. [Modelling of books for technology and IT] issued by UR Rzeszów 2004.

(16) Wołk Z.: Ksztaltowanie kultury technicznej uczniów liceów ogólnoksztatcacych. [Shaping technical culture for grammar school students] issued by Zielona Góra 1990.

\section{Waldemar LIB, dr \\ University of Rzeszow, Poland \\ Institute of Technology \\ 16 A, Rejtana Street \\ 35-310 Rzeszów \\ libw@univ.rzeszow.pl}

